\title{
The Skills and Autonomy of Female Part-Time Work in Britain and Sweden
}

\author{
Karin Halldén ${ }^{a}$ (corresponding author) \\ Duncan Gallie ${ }^{\mathrm{b}}$ \\ Ying Zhou ${ }^{\mathrm{c}}$ \\ ${ }^{a}$ The Swedish Institute for Social Research, Stockholm University, SE-106 91 Stockholm, \\ Sweden. Email: karin.hallden@,sofi.su.se. Phone (office): + 46 (0) 81628 62. Fax: + 46 (8) \\ 154670. \\ ${ }^{\mathrm{b}}$ Nuffield College, Oxford University, New Road, Oxford, OX1 NF, United Kingdom. \\ Email: duncan.gallie@nuffield.ox.ac.uk. \\ ${ }^{c}$ Nuffield College, Oxford University, New Road, Oxford, OX1 NF, United Kingdom. \\ Email: ying.zhou@nuffied.ac.uk. \\ ${ }^{1}$ School of Management and Law, University of Surrey, Guildford, Surrey, GU2 7XH, \\ United Kingdom.
}




\begin{abstract}
Most OECD countries have experienced an increase of female part-time employment in the last decades. It has been argued that part-time work may give greater employment flexibility, enabling mothers to reconcile conflicting demands of family and work and thereby facilitating their integration into the wage economy. At the same time, it has been suggested that female part-time work implies segmentation of the labour force into a core and a periphery, with marginalized, low qualified jobs for part-time employees. However, little attention has been given the possible mediating effect of the institutional context on potential job quality disadvantages of part-timers. We examine this question by comparing the skills and autonomy of female part-time workers in two countries, Britain and Sweden, often considered representing quite distinct forms of institutional regime. The results show that female part-time employees in Sweden hold positions of higher skill and have more autonomy compared to their equivalents in Britain. Even so, both British and Swedish parttime employees face relative disadvantage when compared to female full-time workers. We conclude that differences in the institutional systems of Sweden and Britain do have a significant effect on the absolute skill level of part-time work. However, the relative disadvantage of part-timers persists despite Swedish policies giving greater salience to improvements in the quality of work.
\end{abstract}

\title{
Keywords
}

female part-time, job quality, skills, autonomy 


\section{Introduction: Job Skills and Part-Time Work}

Part-time work exists in countries with very different institutional systems of skill formation and employment regulation. Relatively little is known about how this affects the quality of such jobs. This paper seeks to address this issue by comparing the skill level and autonomy of part-time work in two countries - Britain and Sweden - that are often considered to represent quite distinct forms of institutional regime, embodying very different approaches to labour market flexibility and the integration of vulnerable labour groups.

While the broad correspondence in many countries between the growth of female employment and the expansion of part-time work pointed towards its value in enhancing the integration of women into the labour market (Sundström, 1991, 1993, 2003), a significant body of research suggests that women taking up part-time work are channeled into a quite distinct low-skilled sector of the labour market. They were found to be in lower skilled jobs (Gallie et al., 1998; Tam, 1997), to have lower pay (Bardasi \& Gornick, 2008; Fouarge \& Muffels, 2009; Gornick \& Jacobs, 1996; Kalleberg et al., 2000; Manning \& Petrongolo, 2008), reduced access to employment benefits, such as pensions, sick pay, health insurance and unemployment benefits (Gallie et al., 1998; Ginn \& Arber, 1998; Kalleberg et al., 2000; Rubery et al., 1998), and more limited opportunities for career advancement (Gallie et al., 1998; Russo \& Hassink, 2008; Tam, 1997). There has been less agreement about whether part-time work is associated with lower job security (Båvner, 2001; Gallie et al., 1998) and about whether it constitutes a 'bridge' or a 'trap' with respect to longer-term careers (Anxo et al., 2000; Blank, 1998; Blossfeld \& Hakim, 1997; Buddelmeyer et al., 2005a; Connolly \& Gregory, 2008, 2010; Nätti, 1995; O’Reilly \& Bothfeld, 2002; Smith et al., 2000; Sundström, 2003).

\section{Employment Structure, Skill Formation Regimes and Welfare Systems}

While the disadvantages of part-time work with respect to skills and pay are now wellestablished, there has been less direct comparative research to assess how far part-time work differs in quality between countries ${ }^{1}$. It seems plausible that the extent of disadvantage will be affected by the institutional context of employment, for instance the coverage of collective bargaining, the nature of labour regulation, the structure of skill formation and the welfare system (Anxo et al., 2000; Bardasi \& Gornick, 2008; Blossfeld \& Hakim, 1997; Buddelmeyer et al., 2005b; Daune-Richard, 1998; Ellingsæter, 1995; Fagan \& Rubery, 1996; Fouarge \& Muffels, 2009; Nätti, 1995; O’Reilly, 1994; Rosenfeld \& Birkelund, 1995; Smith et al., 2000).

A particularly interesting comparison with respect to potential institutional effects is between Sweden and Britain, since these are often taken as exemplars of quite distinct institutional regimes. They offer significant contrasts in terms of their structures of employment regulation, their skill formation regimes and their welfare systems.

\footnotetext{
${ }^{1}$ An important exception is O'Reilly's case study comparison of part-timers in the banking industry in France and Britain (O’Reilly, 1994).
} 
With respect to the regulation of employment, Sweden has been characterized as an 'inclusive' employment regime that attaches importance to policies that seek to protect weaker categories of the workforce (Gallie, 2007). Inclusive employment regimes, where the unions play a central role in national decision-making mechanisms, are thought to give priority to high and stable employment across the labour force. As such they should be concerned not only to encourage female labour market participation, but also to ensure that women have jobs that provide stable employment integration, by enabling them to develop their skills. In contrast, Britain is the prime example of a 'market' employment regime, that allows employment to reflect the priorities of the market and that minimizes the safety net for more vulnerable groups. The logic of a market-driven approach implies increased likelihood of part-timers being in low-skilled work, since employers are reluctant to invest in employees who work shorter hours or are more likely to be absent or leave the workforce to assume caring responsibilities.

The implications of this argument would lead to the expectation that part-timers would be in more skilled jobs in Sweden. Swedish part-timers are more likely to share the general employment rights enjoyed by full-timers and to have access to similar training and career provisions. They are also provided with easier transitions between part-time and full-time work. Swedish parents with children below the age of eight have the right to reduce their working hours (up to one fourth of the time). In contrast, although British employers have to consider requests for changed working hours seriously, they have the right to decline. Moreover, in terms of increasing weekly working hours, Swedish employees working parttime have priority with respect to vacant full-time positions.

The two countries in focus, i.e., Britain and Sweden, have also been viewed as having quite different types of skill formation system (Soskice, 1999). Sweden is cited as one of the main examples of a coordinated market economy that places a central importance on the development of high level specific skills that are needed for the more complex work processes associated with 'diversified quality production'. In contrast, Britain has been taken as a paradigm case of a liberal market economy, where employers rely on general skills drawn from the school system. Over all it is argued that an emphasis on specific skills should lead to better quality working conditions, as it increases employees' bargaining leverage (Soskice, 1999). But Estévez-Abe (2005) has suggested that such systems have very different implications for men and women. It is men that are likely to benefit primarily from a specific skills regime, while women may be sharply disadvantaged. This is due partly to the greater difficulty and lower incentives for women to acquire specific skills, given their more frequent career interruptions, and partly to statistical discrimination on the part of employers who are reluctant to train employees who they think may have extended periods away from work. Women are therefore likely to be channeled into a distinct lower skilled sector of the employment structure, with higher levels of gender segregation and poorer quality jobs. Hence, there would be no expectation that female part-timers in a coordinated market system such as Sweden would be better placed than in a liberal market regime like Britain.

Finally, Sweden and Britain have been depicted as strongly contrasting types of welfare regime (Esping-Andersen, 1990). Whereas Sweden can be characterized as a 'universalistic' system that has been particularly favourable to measures to facilitate female participation in the labour market through the provision of paid maternity leave and strong childcare support, Britain is taken as an example of a liberal welfare regime that has been reluctant to 
invest in widespread state childcare provision. The extent to which childcare and after school activities are publicly provided or subsidized may affect the ability of female part-timers to exercise choice in their selection of a job. Better provision reduces constraints of caring responsibilities over working hours. Arguably, where employees can choose between different work hour schedules they will attach a higher importance to job quality and this should place a pressure on employers to enhance the quality of work tasks. Such arguments from welfare would also lead to an expectation that part-time workers would have access to higher skilled jobs in Sweden than in Britain.

The paper addresses these issues by examining the skills and autonomy of part-time jobs in the contrasting institutional conditions of Sweden and Britain. It first discusses the definition of part-time work and the data and measures that will be used, then compares the position of part-timers in the two countries using cross-national data, and finally turns to the question of whether or not there is a difference in the relative skill position of part-timers using national data.

\section{Definitions, Data and Measures}

\subsection{Definitions of Part-Time Work}

A first point to note is that the definition of part-time work is far from unproblematic. Two rather different methods of classifying part-time workers have been used in the literature. The first relies on people's self-definition of their status as a full-time or part-time worker, whereas the second defines part-time work in terms of specific hours of work. A further complication is that 'hours-based' definitions can differ in terms of the number of hours that are seen as separating full-time from part-time employment. In some countries (such as in Britain) the conventional cut off point for part-time work has been 'less than 30 hours', whereas in other countries (including Sweden) those working 35 hours or less have been regarded as part-time employees ${ }^{2}$.

This distinction in conventions about hours-based definitions is partly reflected in patterns of self-definition. Table 1 shows the relationship in the two countries between self-defined part-time status and hours of work, indicating considerable differences between the countries in the typical hours worked by women who are self-defined part-timers. Both British and Swedish self-defined part-timers were to be found in the marginal, short and long part-time hour categories, but there is a notable difference in the relative proportions in each. Whereas nearly one fourth of British female part-timers worked less than fifteen hours a week, this was the case for less than 11 percent of Swedish part-timers. In Britain 65 percent of female part-timers are working short part-time hours, while the corresponding figure for Sweden is 47 percent. With respect to employees in the long part-time category, only 12 percent of the British part-timers worked more than 30 hours a week, whereas in Sweden 43 percent were to be found in the 30 to 35 hours category.

\footnotetext{
${ }^{2}$ It should be noted that individuals working 35 hours a week are sometimes defined as working full-time (for example in the Swedish Labour Force Survey).
} 
Table 1 about here

There is a risk then that, using self-defined status, any differences between part-timers in the two countries may simply reflect different notions of part-time work. Hence, we have based our analysis on two categories of part-time employees, reflecting the differences in the conventional 'hours-based' definitions of part-time work in the two countries. We contrast female employees working short and marginal part-time hours (i.e., less than 30 hours a week, from here on labeled 'short part-time'), and respondents doing 'long part-time' hours (i.e., between 30 and 35 hours) with women working full-time (i.e., more than 35 hours a week).

\subsection{Data}

Our sources of comparative data are the European Labour Force Survey (EU-LFS) 2002 and the European Social Survey (ESS) of 2004. The EU-LFS provides the most robust estimates of class distribution given its very large sample size. The ESS was developed to provide an exceptionally high level of comparability of measures and procedures of data collection ${ }^{3}$. In 2004 it included a special module on Family, Work and Well-Being that incorporated some of the indicators of skill that had been tested over a number of years in British and Swedish national data sets. While the ESS has major benefits in terms of comparability, the sample numbers are relatively small for detailed analysis of subcategories of the workforce. Hence, we have supplemented the comparative data by using larger scale national data sets conducted at a very similar period of time. For Britain we have taken the British Skills Survey (BSS) 2001, which is part of a series of nationally representative surveys that started in 1992 examining trends in skills and in the quality of work. The 2001 survey had an overall sample of 3990 and a response rate of 66 percent (for full details see Felstead et al., 2007).

In the Swedish case, we have used two national data sets - the Swedish Level of Living Survey (LNU) 2000 and the National Swedish Survey of Living Conditions (ULF) 2002. The LNU is carried out by the Swedish Institute for Social Research (SOFI) in collaboration with Statistics Sweden (SCB). This random sample survey of adult persons has been conducted approximately every tenth year since 1968, and examines social conditions with respect inter alia to family, health, employment and living standards. The response rate for the LNU 2000 was 76.6 percent, giving a sample of 5142 individuals (Gähler, 2004). SCB has conducted the ULF yearly since 1975. The survey is based on a national random sample of the adult population and the aim is to present indicators on the Swedish living conditions such as employment, health, social relations and political resources. In 2002 the ULF had a response rate of 74.9 percent giving a net sample of 5973 individuals (Statistics Sweden, 1996).

In both countries the surveys involved face-to-face interviews, carried out in the household, of randomly selected individuals. While the national surveys in the two countries have broadly equivalent measures of skills, they are less appropriate for direct country

\footnotetext{
${ }^{3}$ For detailed information on the European Social Survey, see http://ess.nsd.uib.no/.
} 
comparisons. Thus, we use them then only to test within-nation differences between female full-timers and part-timers. The sample of male part-timers was too small for reliable analysis, so these are excluded. The sample selection for the analyses is employees aged 20 to 60 .

\subsection{Measuring Job Skill}

Our focus is on the skills required by jobs rather than on the individual's personal skills. We follow Spenner (1990) in taking job skill to refer to the 'substantive complexity' of job tasks, in terms of the level, scope and integration of mental, manipulative and interpersonal tasks. A broad measure of job skills is sometimes taken to be occupational class (Tåhlin, 2007). But, as a number of researchers have argued (Felstead et al., 2007; Spenner, 1990), substantive complexity is more closely proxied by the learning time necessary to develop the knowledge required to be able to do the job. This type of measure has the advantage that it can distinguish skill differences within the heavily aggregated class categories. We distinguish two types of learning: pre-job entry learning (the duration of general education and training required for the job) and initial on-the-job learning. These are operationalised in broadly similar ways in the European Social Survey 2004 and the national surveys. In the ESS the wording of the measures was (see Appendix A for the national surveys):

Pre-entry learning: 'If someone was applying nowadays for the job you do now, would they need any educational or vocational schooling beyond compulsory education?'. Those who answered 'Yes' were then asked: 'About how many years of education or vocational schooling beyond compulsory education would they need?': (1) 'Less than 1 year (beyond compulsory school)'; (2) 'About 1 year'; (3) 'About 2 years'; (4) 'About 3 years'; (5) 'About 4-5 years'; (6) 'About 6-7 years'; (7) 'About 8-9 years'; (8) '10 years or more (beyond compulsory school)'.

Initial on-the-job learning: 'If somebody with the right education and qualifications replaced you in your job, how long would it take for them to learn to do the job reasonably well?': (1) '1 day or less'; (2) '2-6 days'; (3) '1-4 weeks'; (4) '1-3 months'; (5) 'More than 3 months, up to 1 year'; (6) 'More than 1 year, up to 2 years'; ( 7 ) 'More than 2 years, up to 5 years'; (8) 'More than 5 years'.

In addition to job skills referring to the 'substantive complexity' of job tasks, Spenner (1983, 1990) also recognizes skills as conceptualized by 'autonomy-control' or 'task discretion' - the ability to exercise control and initiative over the way the job task is done. We have then included as a third skill indicator a measure of task discretion/autonomy based on the following three measures in the ESS 2004 (see Appendix A for the national measures):

'How much [does] the management at your work allow you...'

'...to decide how your own daily work is organized?'

'...to influence policy decisions about the activities of the organization?

'... to choose or change your pace of work?'

The response scale ranges from: (0) 'I have no influence', to (10) 'I have complete control'. As these items had a high scale alpha (0.86), we take the average score over the three items as a summary measure. 
In examining the relationship between female part-time work and job skills, we estimate the initial or gross effects and the effects after a range of demographic factors, human capital and occupational characteristics have been adjusted. The demographic variables were sex, age $^{4}$, partnership status, and the presence of a child under five in the household ${ }^{5}$. The human capital and occupational variables included in the analyses were respondent's education, tenure (years worked for current employer), occupational class, industry, union membership, permanent/temporary contract and public/private sector ${ }^{6}$. See Appendix A for a description of the variable construction.

\section{The Job Skills of Part-Time Employees: A Comparative Overview}

Were there notable differences in the skill requirements of the jobs of full-time and part-time workers in the two countries? We start by examining the distribution of female part-timers by occupational class, then continue with the 'learning time' measures and look finally at the task discretion/autonomy measure of skill.

\subsection{The Distributions of Female Part-Time Employees by Occupational Class}

To compare the distributions of part-time jobs in terms of occupational class, we have converted the occupational data of the EU-LFS for 2002 into the ESeC European Socioeconomic Classification. This classification was developed to be an improved version of the Erikson-Goldthorpe (EGP) categories that have been argued to be good proxies of skill (Rose \& Harrison, 2010; Tåhlin, 2007).

The class distributions of full-time and part-time employees are shown in Table 2. Taking first male full-time employees, it can be seen that there is a broad similarity between the two countries across much of the class structure. In both Sweden and Britain just over a third of those in employment are in managerial and professional occupations. A further fifth are in the 'intermediate' and 'lower service and sales' white-collar categories. Approximately a quarter of employees are in the lowest class of 'routine' workers. Female full-timers are more likely to be found in intermediate and lower sales/service occupations compared to their male counterparts in both Britain and Sweden and they are notably less likely to be in nonskilled 'routine' occupations.

Table 2 about here

\footnotetext{
${ }^{4}$ Since there is a high correlation between age and labour market experience the latter is not included in the analyzes.

${ }^{5}$ We also ran the analyses on ESS 2004 data using a variable indicating the presence of children below the age of 16 in the household, which did not change the results.

${ }^{6}$ Sector was not available in the ESS 2004 data.
} 
Turning to female part-timers, in both countries they are much less likely than full-time working men and women to be in professional-managerial positions. Among those working less than 30 hours, only approximately 14 percent in Britain and 16 percent in Sweden are in such positions, with the proportions being a little higher among those working long parttime hours (21 per cent and 23 per cent respectively). In contrast, female part-timers are considerably more likely to be in 'lower services and sales' positions. Finally, it should be noted that part-timers do not stand out in either country as being heavily over-represented in the lowest occupational positions of all - routine occupations. In both countries it is male full-time workers who are most likely to be in such jobs. The proportion in routine jobs for both categories of part-timer in Sweden is very close to that of female full-timers and the same is the case for long hour part timers in Britain. But British short hour part-timers are considerably more likely to be in routine work than female full-timers.

Comparing part-timers across countries, there is relative little difference between Sweden and Britain in terms of the proportions in managerial and professional positions. There is some variation in the middle stretches of the class structure, with a higher proportion in Britain in intermediate (clerical), and a lower proportion in lower sales and services. It is also notable that there is a difference in the proportions of short hour part-timers in the lowest class positions. While approximately 18 percent of female short hour part-timers are in these positions in Britain, this is the case for only 12 percent in Sweden.

Variations in the middle of the class structure are difficult to interpret in terms of job skills and may primarily reflect different principles of organizational design. But the proportions in managerial and professional occupations on the one hand, and in routine occupations on the other are likely to signal the relative integration of part-timers into better or worse quality jobs. This evidence would indicate that there is very little difference between the two countries in the extent to which part-timers are integrated in the highest level jobs. In both cases, they remain substantially under-represented. However, there is a difference in the extent to which they are to be found in the lowest level jobs, since a higher proportion of the British short hour part-timers are found in such very low skilled work.

\subsection{Job Skills: Learning Time and Task Discretion}

Class categories are inevitably relatively broad and class comparisons may not pick up important within-class differences in job quality. We turn next, then, to compare part-timers in the two countries in terms of more specific indicators of job skills. We take first two indicators of 'substantive complexity' - the pre- and post-entry learning times required to do the job, and then turn to an indicator of task discretion/autonomy.

Table 3 shows that, in both countries, female part-time workers tended to be in jobs that require less post-compulsory education and training than full-timers. However, there is a striking difference between the two countries. Jobs in Sweden have generally higher levels of education and training requirements. Approximately half of the British male and female fulltimers were in jobs that required one year or less of additional education or training, while this was the case for only 26 percent for their Swedish equivalents. Moreover, the Swedish advantage on this skill measure was just as evident among female part-timers. Indeed, 14 and 23 percent of the female British part-timers working short and long part-time hours held jobs that required four years of training or more, while these proportions were approximately 10 percentage points higher for Swedish women working part-time. 
While there can be little doubt about the higher skill level of Swedish female part-timers in terms of pre-entry education, it could be argued that this may be compensated by more extensive learning in the initial period after people take up the job. Our second measure seeks to address this. In both countries, part-timers are again lower on this measure of skill compared to full-time employees. However, in Britain a higher share of female part-timers compared to Swedish women holding part-time jobs reported that the initial learning time required was three months or more.

There is some support then for the idea that there may be compensatory learning mechanisms for low pre-entry learning and that the initial measure may underestimate the skill requirements of the jobs of British part-timers. Nonetheless, it should be noted that the majority of initial on-the-job training spells for female part-timers were relatively short in both countries (between one week to three months). The proportion of long hour parttimers who had more than a year of such training was only 8 percent in both Britain and Sweden, while the respective figures for short hour part-timers were 11 percent and 2 percent. Hence, it seems likely that any compensatory on-the-job training effect was at best very partial.

\section{Table 3 about here}

Finally, in an important part of the sociological literature on work, task discretion, or autonomy, has been regarded as a key component of skill (Spenner, 1983, 1990). As can be seen in the final row of Table 3, in Britain male and female full-timers had higher task discretion scores than female part-timers overall. In Sweden, however, the task discretion of women working long part-time hours is similar to or higher than that of male and female full-timers, although women working less than 30 hours a week also appear disadvantaged in the Swedish case. Comparing part-timers in the two countries, the overall level of task discretion was higher in Sweden than in Britain for women working both short and long part-time hours.

We continue with a more rigorous assessment of the difference of being a female part-time worker in Britain and Sweden using regression analysis. With controls introduced for human capital, occupational class and demographic characteristics, we examine if these factors could account for the differences in job skills and autonomy between British and Swedish parttimers ${ }^{7}$. Statistics describing the control variables can be found in Appendix B, Table B.1. In

\footnotetext{
${ }^{7}$ To take potential differences as regards preferences of work versus family into account (cf., Hakim, 2004) we also ran the analyses including a proxy for work commitment. It was constructed using the following two questions from the ESS 2004: 'For you personally, how important do you think each of the following would be if you were choosing a job?', with one of the five sub questions being: 'A job which allowed you to combine work and family responsibilities?'. The response scale ranged from 1 ('Not important at all'), to 5 ('Very important'). Adding this variable did not change the results in any major way, why it was not included.
} 
order to separate a potential part-time effect from a gender effect, we take female full-timers as the category of reference.

Table 4 about here

Table 4 shows the difference between Swedish and British female part-timers in a model pooling the data for the two countries. It confirms that, compared to their British counterparts, Swedish women working short part-time hours held significantly better jobs in terms of the amount of pre-entry learning required. Also, women working long part-time hours held positions of higher educational requirements in Sweden, but this difference turned insignificant once union membership was introduced. At the same time, there was no significant difference between Swedish and British female part-timers in long or short hours as regards jobs requiring extended learning on initial entry into the post. Swedish part-timers working both long and short hours were in better jobs than their British equivalents with respect to task discretion, even when, inter alia, differences in types of industry, union membership, as well as family status have been taken into account. Most notably, these differences are evident even when class position has been controlled, so they cannot be attributed to the different distribution of part-timers across class positions in the two countries.

The comparative evidence indicates that the jobs of female part-timers in Sweden were better than those of their British equivalents in terms of job skill, as would be anticipated from the view that it was a country characterized by greater inclusiveness and stronger policies to protect more vulnerable categories of the workforce. There were fewer parttimers employed in routine occupations in Sweden, the post-compulsory educational requirements were higher and they allowed employees greater discretion over how they carried out the work.

\section{The Relative Disadvantage of Female Part-Timers within Countries}

Swedish part-timers may be in higher skilled jobs than their British equivalents, but this does not necessarily imply that their relative disadvantage is less. It is possible that the stronger regulative structure of employment in Sweden and the more central role given to employee representation may improve the jobs of workers across the board, still leaving marked differentials relating to contract status. We examine this using national data sets in the two countries that provide considerably larger sample numbers compared to the ESS 2004. It should be remembered that the measures are not identical for the national surveys. Appendix B, Table B. 2 presents statistics describing the control variables.

Taking first the longer hour female part-timers, working between 30 and 35 hours, the estimates (once other factors have been controlled) show a broadly consistent pattern for 
Britain (Table 5). There are no significant differences with respect to either pre-entry schooling, initial on-the-job learning or task discretion, while British women working long part-time hours hold positions that require somewhat less schooling (though only significant on the 10 percent level). Hence, we conclude that there is little evidence that women working longer hour part-time in Britain suffer significant disadvantages in skill terms relative to their full-time equivalents. The Swedish national data shows significant negative effects for both pre-entry schooling and initial post-entry learning, but no significant effect as regards task discretion. Hence, the evidence would suggest that, in contrast to the case in Britain, Swedish longer-hour part-timers are disadvantaged with respect to job skills relative to their full-time counterparts.

The picture for the two countries is reversed for the shorter-hour female part-time workers. For Britain, there are significant negative coefficients across all of the job skill and autonomy dimensions. In Sweden, all coefficients are again negative, indicating that jobs were less skilled than full-timers. However, these are significant only for initial on-the-job learning (on the 10 percent level as regards task discretion) once controls are included.

Table 5 about here

Overall, the results do not support the hypothesis that female part-timers would not experience relative skill disadvantage in Sweden. Both British and Swedish short-hour parttimers were disadvantaged in terms of the skill level of their jobs, but less so in Sweden. The evidence for long hour part-timers indicates that, while there was little difference in Britain between this category and female full-timers, long hour part-timers faced drawbacks in Sweden.

\section{Conclusion}

The aim of the paper has been to examine the effects of different national institutional systems on the skill levels and autonomy of female part-time jobs. There is still relatively little research upon the extent to which the work and employment conditions of part-time jobs vary between societies. We have explored these questions by studying female part-time work in Sweden and Britain - two countries often taken as examples of distinct institutional regimes with respect to skill formation, employment regulation and welfare policies. Different theoretical arguments led to rather different expectations. The view of Sweden as having a more inclusive employment regime and a welfare state that provides better support for working mothers implied that Swedish part-timers' jobs would be of higher skill than those of their British equivalents. Arguments in terms of skill formation regimes gave no grounds for expecting a significant difference in pattern between the two countries. 
In examining the skills and autonomy of female part-time work across the two countries, an initial problem was the need to take account of the rather different conceptions of what constitute part-time hours in Sweden and Britain. We defined two categories of part-time work: long hour part-time work involving between 30 and 35 hours a week and short hour part-time work involving less than 30 hours a week. The former enables us to include the significant proportion of Swedish part-timers who work over 30 hours, while the latter matches the conception of part-time work prevalent in Britain.

Our findings suggest that there is some truth in both of the apparently conflicting theoretical expectations. Swedish female part-timers do hold higher skilled jobs compared to British women working part-time hours. We took three measures of skill - class position, the learning time required for the job (both pre-entry and initial post-entry) and the discretion employees could exercise over how they carried out their work. Part-time working women in Sweden were less likely than part-timers in Britain to be employed in non-skilled work, and they had greater discretion in how work was carried out. In addition, Swedish women working short part-time hours were more likely to be in jobs requiring extended pre-entry schooling It is notable that the differences between part-timers in the two countries were significant even when occupational class had been controlled for, indicating that they were not simply a reflection of differential class distribution. Although the higher pre-entry schooling requirements for short part-time jobs in Sweden may have been partially offset by the tendency of British part-timers to have longer spells of initial on-the-job training, the differences between part-timers in the two countries in this respect were not statistically significant.

However, although Swedish part-timers overall were in jobs with higher skills and autonomy than their British equivalents, this did not imply greater integration in the sense of convergence between the conditions of female full-time and part-time jobs. The relative disadvantage of female short hour part-time employees compared to women working fulltime did seem to be stronger in Britain. But longer hour part-timers were more disadvantaged compared to full-timers in Sweden. One way of interpreting this result is to connect it to the different definitions and distribution of part-time work across working hours in Sweden and Britain. While women working 30 to 35 hours a week are defined as part-timers in Sweden, they are more likely to be seen as full-time employees in Britain. Hence, although Tilly's (1996) distinction between 'secondary part-time workers' (in a peripheral labour market with less skilled jobs) and 'retention part-time workers' (with conditions similar to full-time employees) seems to be applicable to the British labour market, this is not the case in Sweden.

With the caveats that the sample sizes were limited for the comparative data source, and that the measures from the national surveys slightly differ, the findings can be summarized as follows: The results indicate that differences in the institutional systems of Sweden and Britain do have a significant effect on the absolute skill level of part-time work. As with other types of employee, Swedish part-time workers benefit from policies that give much greater salience to improvements in the quality of work. However, the relative disadvantage of female part-timers is not affected by such policies. 


\section{References}

Anxo, D., Stancanelli, E., \& Storrie, D. (2000). Transitions between different working-time arrangements: A comparison of Sweden and the Netherlands. In J., O'Reilly, I. Cebrián, \& M. Lallement (Eds.), Working-time changes. Social integration through transitional labour markets (pp. 93-131). Cheltenham: Edward Elgar.

Bardasi, E., \& Gornick, J. C. (2008). Working for less? Women's part-time wage penalties across countries. Feminist Economics, 14, 37-72.

Blank, R. M. (1998). Labor market dynamics and part-time work. Research in Labor Economics, 17. http://papers.ssrn.com/sol3/papers.cfm?abstract_id=60153

Blossfeld, H.-P., \& Hakim, C. (Eds.) (1997). Between equalization and marginalization. Women working part-time in Europe and the United States of America. Oxford: Oxford University Press.

Buddelmeyer, H., Mourre, G., \& Ward-Warmedinger, M. E. (2005a). Part-time work in EU countries: Labour market mobility, entry and exit. ECB Working Paper Series, 460. Frankfurt: European Central Bank. http://papers.ssrn.com/sol3/papers.cfm?abstract_id=677440

Buddelmeyer, H., Mourre, G., \& Ward-Warmedinger, M. E. (2005b). Recent developments in part-time work in EU countries: Trends and policy. In R., Gómez-Salvador, A., Lamo, B., Petrongolo, M. E., Ward-Warmedinger, \& E. Wasmer (Eds.), Labour supply and incentives to work in Europe (pp. 273-308). Cheltenham: Edward Elgar.

Båvner, P. (2001). Half full or balf empty? Part-time work and well-being among Swedish women. A doctoral dissertation. Stockholm University: Swedish Institute for Social Research Dissertation Series, 49, (Chapter 4).

Connolly, S., \& Gregory, M. (2008). Moving down: Women's part-time work and occupational change in Britain 1991-2001. The Economic Journal, 118, 52-76.

Connolly, S., \& Gregory, M. (2010). Dual tracks: Part-time work in life-cycle employment for British women. Journal of Population Economics, 23, 907-931.

Daune-Richard, A.-M. (1998). How does the 'societal effect' shape the use of part-time work in France, the UK and Sweden? In J. O'Reilly, \& C. Fagan (Eds.), Part-time prospects. An international comparison of part-time work in Europe, North America and the Pacific Rim (pp. 214231). London: Routledge.

Ellingsæter, A. L. (1995). Gender, work and social change. Beyond dualistic thinking. Report 95:14, Oslo: Institute for Social Research, (Chapter 3).

Esping-Andersen, G. (1990). The three worlds of welfare capitalism. Cambridge: Polity Press.

Estévez-Abe, M. (2005). Gender bias in skills and social policies: The varieties of capitalism perspective on sex segregation. Social Politics, 12, 180-215.

European Social Survey (ESS) (10 ${ }^{\text {th }}$ of December, 2010). http://ess.nsd.uib.no 
Fagan, C., \& Rubery, J. (1996). The salience of the part-time divide in the European Union. European Sociological Review, 12, 227-250.

Felstead, A., Gallie, D., Green, F., \& Zhou, Y. (2007). Skills at work, 1986 to 2006.

Universities of Oxford and Cardiff: Centre on Skills, Knowledge and Organisational Performance (ESRC).

http://www.skope.ox.ac.uk/sites/default/files/Skills $\% 20$ at $\% 20$ Work $\% 201986 \% 20$ to $\% 2020$ 06.pdf

Fouarge, D., \& Muffels, R. (2009). Working part-time in the British, German and Dutch labour market: Scarring for the wage career? Schmollers Jabrbuch, 129, 217-226.

Gallie, D. (Ed.) (2007). Employment regimes and the quality of work. Oxford: Oxford University Press.

Gallie, D., White, M., Cheng, Y., \& Tomlinson, M. (1998). Restructuring the employment relationship. Oxford: Oxford University Press, (Chapter 6).

Ginn, J., \& Arber, S. (1998). How does part-time work lead to low pension income? In J. O'Reilly, \& C. Fagan (Eds.), Part-time prospects. An international comparison of part-time work in Europe, North America and the Pacific Rim (pp. 156-173). London: Routledge.

Gornick, J. C., \& Jacobs, J. A. (1996). A cross-national analysis of the wages of part-time workers: Evidence from the United States, the United Kingdom, Canada and Australia. Work, Employment and Society, 10, 1-27.

Gähler, M. (2004). Levnadsnivåundersökningen [The Swedish Level of Living Survey] (LNU). In M. Bygren, M. Gähler, \& M. Nermo (Eds.), Familj och arbete: Vardagsliv i förändring [Family and work: Everyday life in transition] (pp. 322-327). Stockholm: SNS Förlag.

Hakim, C. (2004). Key issues in women's work. Female diversity and the polarisation of women's employment. (2nd ed.). London: Glasshouse Press.

Kalleberg, A. L., Reskin, B. F., \& Hudson, K. (2000). Bad jobs in America: Standard and nonstandard employment relations and job quality in the United States. American Sociological Review, 65, 256-278.

Manning, A., \& Petrongolo, B. (2008). The part-time pay penalty for women in Britain. The Economic Journal, 118, 28-51.

Nätti, J. (1995). Part-time work in the Nordic countries: A trap for women? Labour, 9, $343-$ 357.

O'Reilly, J. (1994). Banking on flexibility: Comparing flexible employment practices in retail banking in Britain and France. Aldershot: Avebury.

O'Reilly, J., \& Bothfeld, S. (2002). What happens after working part-time? Integration, maintenance or exclusionary transitions in Britain and western Germany. Cambridge Journal of 
Economics, 26, 409-439.

Rose, D., \& Harrison, E. (Eds.) (2010). Social class in Europe: An introduction to the European socio-economic classification. London/New York: Routledge/ESA Studies in European Societies.

Rosenfeld, R. A., \& Birkelund, G. E. (1995). Women's part-time work: A cross-national comparison. European Sociological Review, 11, 111-134.

Rubery, J., Smith, M., Fagan, C., \& Grimshaw, D. (1998). Women and European employment. London/New York: Routledge, (Chapter 6).

Russo, G., \& Hassink, W. (2008). The part-time wage gap: A career perspective. De Economist,156, 145-174.

Smith, M., Cebrián, I., Davia, M. A., Hernanz, V., \& Malo, M. A. (2000). Transitions through part-time work in Spain and the United Kingdom: A route into secure employment? In J. O’Reilly, I. Cebrián, \& M. Lallement (Eds.), Working-time changes. Social integration through transitional labour markets (pp. 173-204). Cheltenham: Edward Elgar.

Soskice, D. (1999). Divergent production regimes: Coordinated and uncoordinated market economies in the 1980s and 1990s. In H. Kitschelt, P. Lange, G. Marks, \& J. D. Stephens (Eds.), Continuity and change in contemporary capitalism (pp. 101-134). Cambridge: Cambridge University Press.

Spenner, K. I. (1983). Deciphering prometheus: Temporal change in the skill level of work. American Sociological Review, 48, 824-837.

Spenner, K. I. (1990). Skill: Meanings, methods and measures. Work and Occupations, 17, 399-421.

Statistics Sweden (SCB) (1996). Supplement to appendix 16. Population and welfare statistics. The National Swedish Survey of Living Conditions (ULF). http://www.scb.se/statistik/LE/LE0101/Supplement16.pdf

Sundström, M. (1991). Part-time work in Sweden: Trends and equality effects. Journal of Economic Issues, 25, 167-178.

Sundström, M. (1993). The growth in full-time work among Swedish women in the 1980s. Acta Sociologica, 36, 139-150.

Sundström, M. (2003). Part-time work in Sweden: An institutionalist perspective. In C. le Grand, \& T. Tsukaguchi-le Grand (Eds.), Women in Japan and Sweden. Work and family in two welfare regimes (pp. 121-136). Stockholm: Almqvist \& Wiksell International.

Tam, M. (1997). Part-time employment: A bridge or a trap? Aldershot: Ashgate.

Tilly, C. (1996). Half a job: Bad and good part-time jobs in a changing labor market. Philadelphia: Temple University Press, (Chapter 4). 
Tåhlin, M. (2007). Skills and wages in European labour markets: Structure and change. In D. Gallie (Ed.), Employment regimes and the quality of work (pp. 35-76). Oxford: Oxford University Press. 


\title{
APPENDIX A
}

\author{
Variable Construction
}

\section{Dependent Variables (national data sources)}

\section{Britain}

Pre-entry learning: 'If they were applying today, what qualifications, if any, would someone need to get the type of job you bave now?' The highest qualification given was subsequently allocated to one of six broad qualification categories: (0) 'No qualifications'; (1) 'Poor lower secondary'; (2) 'Lower secondary'; (3) 'Upper secondary'; (4) 'Non-degree higher education'; (5) 'Degreelevel higher education’.

Initial on-the-job learning: 'How long did it take for you, after you first started doing this type of job, to learn to do it well?: (1) 'Less than 1 week'; (2) 'Less than 1 month'; (3) '1 month and over, up to 3 months'; (4) ' 3 months and over, up to 6 months'; (5) ' 6 months and over, up to 1 year'; (6) '1 year and over, up to 2 years'; (7) '2 years and over'.

Task discretion: 'How much influence do you personally have on deciding how you are to do the task??: (1) 'A great deal'; (2) 'A fair amount'; (3) 'Not much'; (4) 'None at all'.

\section{Sweden}

Pre-entry learning: 'Is any schooling or vocational training above elementary schooling necessary for your job? 'Yes'/'No'. [If yes]: 'About how many years of education above elementary school are necessary?' Number of years.

Initial on-the-job learning: 'Apart from the competence necessary to get a job such as yours, how long does it take to learn to do the job reasonably well?: (1)'1 day or less'; (2)'2-5 days'; (3)'1-4 weeks'; (4)'13 months'; (5)'3 months - 1 year'; (6)'1-2 years'; (7)'More than 2 years'.

Task discretion: 'What degree of influence do you think that you personally have on the planning of your work?: (1) 'None; (2)'Some'; (3) 'A lot'.

Independent Variables (for both Britain and Sweden)

Male full-timer is a dummy variable taking the value 1 for men working more than 35 hours a week.

Female full-timer is a dummy variable taking the value 1 for women working more than 35 hours a week.

Long part-timer work is a dummy variable taking the value 1 for female employees working between 35-30 hours a week. 
Short part-timer work is a dummy variable taking the value 1 for female employees working less than 30 hours a week.

\section{Human Capital and Occupational controls}

Education is a dummy variable based on one digit ISCED-97 ('International standard classification of education 1997'), which takes the value 1 if the respondent has post secondary or tertiary education.

Tenure is a continuous variable measuring the number of years working for the current employer. A squared term of tenure has also been included in the analyses.

Occupational class consists of the following six categories classified in accordance with the simplified version of the European socio-economic classification (ESeC)

(http://www.iser.essex.ac.uk/research/esec/user-guide):

ESeC 1 \& 2 merged: 'Managers \& Professionals'

$\mathrm{ESeC}$ 3: 'Intermediate occupations'

ESeC 6: 'Lower supervisors \& Technicians'

ESeC 7: 'Lower Sales \& Service'

ESeC 8: 'Lower Technical

ESeC 9: 'Routine'

Individuals working in armed forces, as well as self-employed (i.e., ESeC 4 and 5), were excluded. In addition, the two highest ESeC classes, 'Managers' and 'Professionals' (i.e., ESeC 1 and 2) were merged into one category.

Industry is a variable with the following five categories based on one digit NACE ('Nomenclature statistique des activités économiques dans la Communauté européenne'): 'Transformative industry' ('Agriculture, hunting and forestry', 'Fishing', 'Mining and quarrying', 'Manufacturing', 'Electricity, gas and water supply', and 'Construction').

'Consumer industry' ('Wholesale and retail trade', 'Hotels and restaurants', and 'Transport, storage and communication').

'Financial sector' ('Financial intermediation', and 'Real estate, renting and business activities'). 'Welfare' ('Public administration and defense', 'Education' and 'Health and social work'). 'Other' ('Other community, social and personal service activities', 'Activities of households' and 'Extra-territorial organizations and bodies').

Union member is a binary variable taking the value 1 if the respondent is a union member.

Temporary employment is a dummy variable with the value 1 for respondents with non permanent employment contracts.

Public sector is a dummy variable taking the value 1 if the respondent works in the public sector (this variable does not exist in ESS 2004).

Demographic Variables and Family Characteristics Age is coded into categories of five year intervals.

Partner is a binary variable taking the value 1 if the respondent is married or is living with a partner. 
Young child in the bousehold is a dummy variable taking the value 1 if the respondent has a child below five years of age in the household. 
APPENDIX B

Descriptive statistics

Table B.1 about here

Table B.2 about here 